\title{
The First Global War
}

\author{
MATUS János ${ }^{1}$
}

\begin{abstract}
The 100 th anniversary of the start of the First World War provides an opportunity to take stock of efforts by the international community regarding the prevention of comparable catastrophes. Rethinking the lessons learned from the first global war in the era of increasing globalisation has special significance. Many authors think that the First World War was preceded by the first era of globalisation. Mutual economic interests could not prevent war in the second decade of the $20^{\text {th }}$ century. Growing hostility among states stopped the process of globalisation. Could it hap-pen again? There is no certain answer to this question. With the help of international institutions states have been able to reduce the risks of major conflict. How-ever, the fundamental roots of conflict still exist. The urgent task of establishing a more harmonious relationship among individuals, societies, governance, economy and the environment, is still ahead of us.
\end{abstract}

\section{Drifting to the War}

It might seem unusual to use the adjective "global" in connection with the war which we usually characterise as "first" or occasionally "great". In addition to the adjective "first", "global" also refers to the fact that in the middle of the second decade of the $20^{\text {th }}$ century the generation of our grandfathers and great grandfathers had to face an unprecedented and dra- matically new situation never experienced before. In the year 2014, the 100-year anniversary of the beginning of the First World War our moral duty is to remember our predecessors who experienced terrible hardships either as soldiers or as civilians. Some of them might just have returned from overseas places where they had been driven in the hope of a better future, but the love of their homeland brought them back. They could not foresee the carnage, which was waiting for them.

Different sources give different numbers for the victims of the war. The most reliable esti- mate about the military casualties is somewhat more than 9.7 million. The number of civilian casualties is more than 10 million. Close to 20 million people died in the war. If we take the number of those who died, were wounded, were taken prisoner of war or were unaccounted for, the number exceeds 37 million.

Hungary had mobilised 3 million 581 thousand soldiers before the war. 1 million 492 thousand of them suffered injuries of different kinds, 833 thousand were captured and be- came prisoners of war, 530,965 thousand died, and only 524 thousand soldiers returned home safely to their families. The Habsburg Monarchy altogether mobilized 7.8 million soldiers for the war. The total losses (dead, wounded, disappeared and prisoners of war) at the end of the war were 7 million soldiers. From all participating countries taken together the ratio of

1 email: matus.janos@chello.hu 
losses compared to the total number of mobilized soldiers in the Monarchy was the largest (90\%). The other great powers' ratio of losses was as follows: Russia 76.3\%, France $73.3 \%$, Germany $65 \%$. Regarding the absolute number of fatalities the greatest losses were suffered on the side of the Entente Cordial, by Russia and France, and on the side of Central Powers Germany and the Austro-Hungarian Monarchy. [1: 1-2]

Another important element of recollection is acknowledging the consequences of the remaking of the international order following the Versailles Peace Treaty. In this regard Hun- gary, which separated from the Monarchy and became an independent state, was subject to the greatest losses by losing $2 / 3$ of its territory and $1 / 3$ of its population. The analysis of the historical context and the wider consequences of the Trianon Peace Treaty exceed the frame- work of this paper. However, it should be mentioned that both in Europe and in other parts of the world significant changes took place. The colonial system changed. Germany lost its former territories. New states emerged in the place of the Ottoman Empire. The League of Nations created the Trusteeship System with the inclusion of the victorious great powers which had been entrusted to prepare non-self-governing territories for independence.

Why can we use the adjective "global" to characterize World War One? The first reason is that the number of participants in that war was unprecedentedly higher than that of any other previous wars. The number of countries which were somehow involved in the war ex- ceeded 100. The greatest losses were suffered by the 15 - mostly European - countries that participated in the war from the beginning to the end. European colonial powers mobilized their colonies as well and relied on their human and material resources. In this way the entire African continent was involved in the war. There were countries which expressed solidarity with actual participants on either side of the war. The entrance of the United States to the war on $6^{\text {th }}$ April 1917 was followed by the symbolic declaration of war against the Central Powers by a number of Central American countries. Denmark, Sweden and Switzerland in Europe, Argentina, Bolivia and Paraguay in South-America opted for neutrality. However, the war caused considerable economic losses to them as well. [2]

Another argument supporting the use of the adjective "global" is that by the middle of the $19^{\text {th }}$ century the international system expanded and became global in a geographic sense. Technological innovations in the field of transportation and communications shortened dis- tances substantially, accelerated interactions among countries and made economic relations mutually beneficial and less expensive. According to statistical data, and their interpretation by contemporary experts, by 1913 the ratio of international trade in relation to GDP of the countries reached a level which can be compared to the level of globalisation today. Inter- national trade and finance made countries interdependent in a way never experienced be- fore. Norman Angell, British journalist, in his book "The Great Illusion" published in 1910, qualified war as irrational and impossible due to the mutually beneficial impact of economic relations among countries. In the years before the war the German commercial fleet had been insured by the British Lloyd Company. According to the legal opinion of the lawyer of the Lloyd Company, in case of war the Company would have been obliged to compensate Ger- many for the damage caused by the British Fleet. [3: 37-38]

In $19^{\text {th }}$ century military strategy, first of all, the planning of military operations, was great- ly influenced by such innovations as the telegraph, telephone, radio and railways. In the military organisations the General Staff became a revolutionary new element with the func- tion of planning war in peace time against potential enemies. In the second half of the $19^{\text {th }}$ 
century new firearms were introduced in the armed forces, which dramatically increased the casualties of war. In the Italian war of independence the tragic consequences of the Battle of Solferino in 1859 led to the creation of the International Red Cross with the aim of offering help to the victims of war. [4: 334] Further examples of the dramatically increasing destruc- tive potential of new firearms were given by the Austro-Prussian war in 1866 and the Rus- soJapanese war of 1904. The increasing effectiveness of military organisations, first of all the introduction of General Staff was underlined by the Franco-German war of 1871 where the Prussian forces achieved quick military success followed by the unification of Germany.

Looking at important events at the turn of the $19^{\text {th }}$ and $20^{\text {th }}$ centuries one could easily find convincing arguments against a future war. However, the continuation of the cycles of European history, the periodic return of massive violence proved stronger. In the course of the four centuries prior to the First World War 106 wars broke out in which European great powers participated in one or both sides. [5: 88-91] One may assume that the outbreak of the war in the summer of 1914 was an immensely destructive continuation of an unavoidable historical process.

The political realist school of international relation theory conclusion, based on lessons from experience and many centuries, assumes that actors of international relations consider the increase of national power the most important source of promoting national interests. Since power is always relational and relative, its increase unavoidably generates rivalry. Fail- ure in the management of rivalry leads to violence. [6: 60-63] At the turn of the century ri- valry for markets, territories, colonies and the control of communication lines in oceans was growing and mismanaged. After the war there was one encouraging sign to check the naval rivalry among the leading naval powers signified by the Washington Treaty of 1922, which established a ceiling on the number of battleships of the US, UK, France, Italy and Japan. However, this treaty was not sufficient to stop power rivalry on a global scale, competition continued and the scene was set again for another more destructive war in spite of warnings by economic considerations.

When the assassination of the Habsburg archduke in the summer of 1914, followed by an international crisis, foreshadowed the possibility of war, members of two opposing alliances began to calculate the possible solutions of the crisis. Austria wanted to take revenge on Ser- bia by demanding the right to investigate the circumstances of the assassination, and it also saw military action as a possible punishment. In defence of her sovereignty Serbia rebuffed the Austrian demand. Germany assured Austria of her full support. Serbia enjoyed total sup- port of Russia against Austria. After the opening up of diplomatic archives the general public learned that a short local war between Austria and Serbia would have been acceptable for a number of European countries. The fact, that the General Staff of the German armed forces had ready-made operational plans for war against France and Russia separately and also for two parallel wars underlines the assumption that Germany was ready to risk a European war. On the other hand Germany had been making tireless efforts to ensure the neutrality of Great Britain in order to avoid a world war.

Since Germany failed in her efforts the conflict arising out of the assassination in Saraje- vo led to war. The sequence of declarations of war by itself is an indication of which countries strove for a military solution in the first place. On July 28 Austria declared war on Serbia. On August 1 Germany declared war on Russia. On August 3 Germany declared war on France. On August 4 Germany declared war on Belgium and Great Britain declared war on Germany. 
A number of specialists are of the opinion that the rival military blocks drifted into a war which they had not intended. [7]

This experience has served as an important starting point for the researchers of the in- ternational system. Researchers of causes of conflicts and wars extended their work to those aspects of perception and thinking of individual people which might lead to misperception of reality especially the irrational perception of animosity in the relationship of peoples and nations.

Military history concluded important lessons from the First World War. One of the most important lessons has been that military strategy must be in harmony with the technical features and operational use of weapons. In the era preceding the war the dominant military strategy favoured offensive operations as important preconditions of military success. This assumption was based on the experiences of the Napoleonic wars. Modern firearms, most im- portantly machine guns, which were available during World War One, substantially increased the effectiveness of the defender against the attacker. Military strategists did not realise this important change in time, consequently the war turned into trench warfare with the loss of mobility. The use of poisonous gases intended to find a way out of this impasse and contrib- uted to the increase of the immensely inhuman nature of the war. In the second and third year of the war aircraft and tanks increased the mobility of warfare and these new weapons also contributed to the vastly destructive nature of the next war. [8: 16-27]

After the first global war the states did not draw the proper conclusions and were not able to create international mechanisms which could have prevented the next war. The cyclical return of war was stopped after the Second World War, at least in Europe. Integration which started with economic cooperation and gradually extended to other areas of international relations played a decisive role in this development. Conflicts of interests, crises and violent conflicts have remained in the relationship of states, but efforts aimed at the management of conflicts and crises are much more efficient now than 100 years ago.

\section{New Approach to Crisis Management}

The significance of multilateral diplomacy and permanent forums of negotiations were real- ised more than 3 centuries ago during the reign of Louis XIV of France. [9: 18-19] However, this invention in diplomatic method was not efficient in the prevention of war until quite re- cently. The creation of the United Nations Organisation marks the beginning of a slow grad- ual process which helped states to develop more efficient capabilities for war prevention. On the military side nuclear weapons represented a qualitatively new capability for deterrence of aggressive behaviour by possible adversaries. On the side of diplomacy the proliferation of international regimes and institutions was the most important development. The relative peace of the past 6-7 decades can be attributed to the combined use of these two essential means of security policy by states. Throughout history military means have always been more influential and stronger than diplomacy. An international crisis had always mobilised military response more easily than the arduous negotiating efforts of diplomats. Increased interactions of representatives of states in international institutions helped to realise the im- portance of negotiations. Diplomats within this new context of interactions could easily learn more accurate information about the intentions of other states. This has been a fundamentally new opportunity to have a separate view on the military capabilities on one hand and the 
intention to use those capabilities by states on the other. Misperceptions regarding these two aspects of international conflict were very often the additional causes of war beyond funda- mental conflicts of interests.

International institutions stand for a peaceful resolution of conflicts. The use of a military option is always the last resort. Individual countries however, have to face more difficult di- lemmas because of the ambiguity of the situation they find themselves in. This is the reason why governments very often have greatly diverging views on the use of force in a certain situation. There are ambiguities even in the Charter of the United Nations in connection with the permissibility of the use of force. Chapter I, article 2, section 4 requires all members of the United Nations to "refrain in their international relations from the threat or use of force against the territorial integrity or political independence of any state, or any other manner inconsistent with the purposes of the United Nations." Legal experts consider this part of the Charter as a clear prohibition of the use of force. However, diplomats in the UN very often quote article 51 of the Charter in support of the use of force in certain situations. [10: 113] This diverging understanding of the letters and the spirit of the Charter of the UN has been the source of intense debate in the Security Council especially in the era of Cold War.

In the past decades on a national level experts made attempts to develop concepts on cri- sis management relying on the combined use diplomacy and military force. These concepts emphasise the need for strict political control over the use of military force in any crisis situ- ation. Military operations must stop when signals indicate the chances for diplomatic moves. Military operations must always be strictly coordinated with diplomatic negotiations. Mil- itary moves are supposed to indicate resolve and commitment to achieve certain goals and defend ones' interests. Diplomatic moves should indicate the devotion to negotiations and a peaceful solution of conflict. The combination of diplomatic and military actions should demonstrate to the opponent that there is a way out from the crisis without endangering its fundamental interests. [11:25]

More careful management of conflict and crisis among states contributes to a more peace- ful world in the post-World War two period. However, after the Cold War, new sources of conflict and unprecedented forms of crises have emerged in the relationship of states and within states. There is a need for a new and more complex approach to national and interna- tional security in the context of looking for a more stable and more just world. A more careful study of human behaviour has already made important contribution to better understanding of the root causes of conflict. This new approach suggests that conflict originates in the mind of people as a result of socialisation, especially regarding the satisfaction of basic human needs. According to the results of the study of human behaviour the satisfaction of individuals regarding their needs, values and interests determines whether their actions will be driven by cooperation or conflict. [12: 32-33] This suggestion is becoming increasingly important when inequalities and gaps in material wellbeing and consequently division among people and nations are becoming dangerously deep. 


\section{References}

[1] History Learning Site. First World War Casualties. 2014. www.historylearningsite.com.uk/FWWWcasualties.htm (downloaded: 0604 2014)

[2] About.com, About Education, European History. 2014. www.europeanhistory.about.com/od/worlwar1/a/www1 countriescon.htm (downloaded: 21 05 2014)

[3] AHAMED, L.: A pénzvilág urai. Budapest: Corvina Kiadó Kft., 2012.

[4] Encyclopaedia Britannica: The New Encyclopaedia Britannica Micropaedia. Volume IX. 1977.

[5] LEVY, J. S.: War in the Modern Great Power System 1495-1975. Lexington: The University Press of Kentucky, 1983.

[6] MATUS J.: A jövö árnyéka. Budapest: A Pesti Csoport Kft., 2005.

[7] LEVY, J. S.: The Role of Crisis Management in the Outbreak of World War I. In. GEORGE, A. L. (Ed.): Avoiding War: Problems of Crisis Management. Boulder, Colorado: Westview Press, 1991. 62-102.

[8] HART, L.: National Object and Military Aim. In. THIBAULT, G. E. (Ed.), Dimensions of Military Strategy. Washington, D.C.: National Defence University, 1987.

[9] Soviet Diplomacy and Negotiating Behaviour: Emerging New Context for U.S. Diplomacy. Washington, D.C.: U.S. Government Printing Office, 1979. https://doi.org/10.2307/1961478

[10] SCHEFFER, D. J.: The Great Debate of the 1980's. In. EHRLICH, T., O'CONNELL (Eds.), International Law and the use of Force. New York: Little, Brown and Company, 1993. [11] GEORGE, A. L.: A Provisional Theory of Crisis Management. In. GEORGE, A. L. (Ed.), Avoiding War. Boulder, Colorado: Westview Press, 1991.

[12] BURTON, J. W.: Conflict: Resolution and Provention. New York: St. Martin's Press, 1990. 